\title{
GRAPE POMACE EXTRACT AS GREEN VAPOR PHASE CORROSION INHIBITOR
}

\author{
Viktoria Vorobyova1, Olena Chygyrynets'1, ${ }^{*}$, Margarita Skiba ${ }^{2}$, Inna Trus ${ }^{1}$, \\ Svitlana Frolenkova ${ }^{1}$
}

https://doi.org/10.23939/chcht12.03.410

\begin{abstract}
The inhibition effect of the grape pomace extract during the early stage of steel corrosion under adsorbed thin electrolyte layers was investigated. The present study was carried out to identify the components present in the 2-propanol grape pomace extract by GCMS analysis. Gravimetric, electrochemical impedance spectroscopy, potentiodynamic polarization, scanning electron microscopy, and FTIR techniques were used to study the corrosion inhibitive. Polarization measurements have indicated that these green inhibitors acted through mixed type inhibition. SEM studies have evidenced the formation of a protective film over metal surface while FTIR supported by molecular modelling has proved that this shielding effect was caused by aldehydes particularly 2-phenylacetaldehyde and 3,7-dimethylocta-2,6-dienal.
\end{abstract}

Keywords: grape pomace extract, volatile corrosion inhibitor, aldehyde, quantum-chemical calculation.

\section{Introduction}

Among the various methods available for protection of metals from corrosion during storage and transportation, the use of volatile corrosion inhibitors (VCI) occupies a unique place [1-3].

The VCI are known to have extended corrosioninhibiting properties to a metal surface due to their volatilization within an enclosed space. As VCI, several thousands of compounds of various chemical classes have been investigated and recommended but most of them do not meet the contemporary ecological and economic requirements. Moreover, new requirements are imposed on the methods of their manufacturing. The organization

\footnotetext{
${ }^{1}$ National Technical University of Ukraine «Igor Sikorsky Kyiv Polytechnic Institute»,

37, Peremogy Ave., 03056 Kyiv, Ukraine

${ }^{2}$ Ukrainian State Chemical-Engineering University,

8, Gagarina Ave., 49005 Dnipro, Ukraine

*corrosionlife@gmail.com

(C) Vorobyova V., Chygyrenets' O., Skiba M., Trus I., Florenkova S., 2018
}

of the process of multistage synthesis is a complex and high-cost process. Environmental sustainability concerns and the elevated costs of synthetic inhibitors motivated the search for less expensive and environmentally friendly alternatives such as corrosion inhibitors derived from natural products. This is why the VCI, which preparation in the ideal case is reduced to a simple mixing of components prove to be the most promising. Hence, it is important to develop volatile inhibitors of atmospheric corrosion which are characterized not only by high efficiency and environmental safety, but also by a simple preparation procedure. As promising raw materials for the development of VCI, organic substances of vegetable origin can be mentioned. It is explained by the fact that natural raw materials contain a large number of biologically active substances and the process of extraction is more cost-efficient than chemical synthesis [6-9].

As one of these sources, we can use products of processing the grapes - pomaces (Vitis vinifera family). Grape pomace is an industrial waste from wine and juice processing, and it primarily consists of grape seeds, skin and stems. Grape pomace extract contains many chemical compounds and can be used as VCI. In the literature, no information about possible applications of the grape pomace and its extracted compounds for the development of anticorrosion materials, especially VCI, can be found. Only several works are devoted to the study of usage of the natural compounds like wood bark oil [10] and thyme $[11,12]$ as VCI. In continuation of our work, some plant extracts have been studied [13-15] as effective volatile corrosion inhibitors of steel, namely rapeseed cake and hope cones.

The aim of the present work is to evaluate the corrosion inhibition effect of grape pomace extract as green volatile corrosion inhibitor for mild steel. Its vapor corrosion inhibition property was evaluated under simulated operational conditions by using the following techniques; potentiodynamic polarization, electrochemical impedance spectroscopy, scanning electron microscopy (SEM), and FTIR analysis. 


\section{Experimental}

\subsection{Samples Preparation}

The corrosion test and electrochemical measurements were carried out using the mild steel strips. The composition of the mild steel (\%): C 0.21; Mn 0.05; P $0.09 ; \mathrm{S} 0.05$ and $0.01 \mathrm{Al} ; \mathrm{P} 0.02 ; \mathrm{Fe}$ is the rest. The strips were polished by emery paper of $1 / 0,2 / 0$ and $3 / 0$, rinsed with double distilled water, degreased, dried at room temperature, and kept in desiccators for 1 day.

Grape pomace extract was prepared by macerating in the 2-propanol alcohol for $48 \mathrm{~h}$ at solid:extraction agent ratio of 1:10 and filtered through ordinary filter paper.

\subsection{G ravimetric M easurements}

Inhibitor effectiveness of the grape pomace extract as a volatile inhibitor of atmospheric corrosion of steel was evaluated by the method of accelerated tests under simulated operational conditions. The final geometrical area was $25 \mathrm{~cm}^{2}$. The gravimetric measurement was conducted by suspending the samples in $250 \mathrm{~cm}^{3}$ conical flask with a tight-fitting rubber cork containing a small dish. The VCI were placed in the dish $(2 \mathrm{ml})$ for a certain period of time (depending on the experiment from 24 to $72 \mathrm{~h}$ ) to form a protective film. After inhibitor film was formed, $15 \mathrm{~cm}^{3}$ of deionized water was added. The test process consisted of cyclic warming and cooling of the samples in a corrosion testing chamber with varying humidity. One cycle involves $8 \mathrm{~h}$ exposure in the thermostat $(313 \pm 1 \mathrm{~K})$, and $16 \mathrm{~h}$ exposure at the temperature of $298 \mathrm{~K})$. The total duration of the tests was 21 days.

Corrosion rates and inhibitor effectiveness were calculated according to the following equations:

$$
\begin{gathered}
C R=\frac{W_{0}-W_{1}}{A \cdot \tau} \\
I E=\frac{C R_{1}-C R_{2}}{C R_{1}} 100
\end{gathered}
$$

where $A$ is a sample area, $\mathrm{m}^{2} ; W_{0}$ is an initial weight of the sample, $\mathrm{g} ; W_{1}$ is the sample weight after the immersion period, $\mathrm{g} ; \tau$ is an immersion period, $\mathrm{h} ; C R_{1}$ and $C R_{2}$ are corrosion rates without and with inhibitor, respectively, $\mathrm{g} \cdot \mathrm{m}^{-2} \cdot \mathrm{h}^{-1}$.

\subsection{Electrochemical Measurements}

To determine the influence of protective surface films on the cathodic and anodic atmospheric corrosion processes (AC) for mild steel, we plotted the potentiodynamic polarization curves for a three-electrode electrochemical cell (the volume of working solution was $60 \mathrm{~cm}^{3}$ ). Cylindrical mild steel electrode pressed into a Teflon holder was used and a platinum plate was used as an auxiliary electrode. The disk end face made of the mild steel electrode with $0.385 \mathrm{~cm}^{2}$ in area served as a working surface. We plotted the polarization curves in $0.5 \mathrm{M}$ $\mathrm{Na}_{2} \mathrm{SO}_{4}$ solution used to model the aggressive medium of the metals AC [16]. The polarization investigations were performed by using PI-50-1.1 potentiostat and PR-8 programmer. Mild steel potential was recorded and reported vs. $\mathrm{Ag} / \mathrm{AgCl} / \mathrm{KCl}$ (sat.).

The electrochemical impedance spectroscopy was measured with open circuit potential of $10 \mathrm{mV}$ alternating voltage and the frequency from $100 \mathrm{kHz}$ to $0.05 \mathrm{mHz}$ with 10 points per decade. The test device and the cell configuration for the EIS measurements were the same as those for the polarization curve tests. To prove reproducibility, the polarization curve tests and the EIS measurements were repeated three times.

\subsection{Gas Chromatography-M ass Spectrometry (GC-MS)}

The composition of volatile substances of the extract was studied by the method of chromatographyand-mass spectrometry by using Finigan Focus gas chromatograph with an HP-5MS capillary column of $30 \mathrm{~m}$ in length and $0.25 \mathrm{~mm}$ in diameter under the following conditions: temperature of injector $523 \mathrm{~K}$; temperature of detector $553 \mathrm{~K}$; thickness of the phase $0.25 \mu \mathrm{m}$; helium as a carrier gas; flow of the carrier gas $1.5 \mathrm{ml} / \mathrm{min}$; the temperature conditions of chromatographic analysis (program) were as follows: an initial temperature of the column $373 \mathrm{~K}$ and a heating rate of the column (temperature gradient) $10 \mathrm{~K} / \mathrm{min}$ up to $553 \mathrm{~K}$; the mass range was 30-500 a.m.u. The components were identified by comparing the peak retention times in the chromatogram and the complete mass-spectrum of individual components with the corresponding results for pure compounds in the NIST-5 Mass Spectral Library. The relative contents of the chemical components of the extract were found by the method of internal normalization of the peaks area without correcting the sensitivity coefficients.

\subsection{Surface M orphology Study (SEM)}

The surface morphology and coating were examined by FEI E-SEM XL 30 (detection of secondary electrons). For SEM images, $1 \mathrm{~cm}^{2}$ sample was taken.

\subsection{Fourier Transformation Infrared Spectroscopic Studies (FTIR)}

FTIR analis was measured by Bruker Tensor 27 FTIR spectrometer in attenuated total reflection mode (Pike Technologies, GladiATR for FTIR with diamond crystal) and using spectral range of $4000-400 \mathrm{~cm}^{-1}$ with resolution of $4 \mathrm{~cm}^{-1}$. 


\subsection{Quantum Chemical Calculations}

The plant extract is a mixture of various components, which results in a complex inhibition mechanism. It is rather difficult to determine what components are present in plant extract create their relatively high ability to inhibit corrosion. However, it remains unknown what molecules of vapour-phase of 2-propanol grape pomace extracts are adsorbed on the steel surface and provides inhibition effectiveness.

According to the literature data [17, 18], the adsorption activity of organic molecules and, hence, their susceptibility to chemisorption can be estimated by the reactivity indices, various electronic structure parameters obtained as a result of quantum-chemical calculations with regard to the electronic and energy characteristics of the inhibitor and the metal. Therefore, a prognostic estimation of the adsorption capacity based on the electronic characteristics of molecules such as energy of the higher occupied molecular orbital $\left(E_{\text {Номо }}\right)$ and the energy of the lower vacant molecular orbital $\left(E_{L U M O}\right)$, the energy of the molecular gap $\left(\Delta \varepsilon=E_{\text {HOMO }}-E_{L U M O}\right)$ was carried out. Calculation of electronegativity and chemical hardness of a molecule was based on the theory of functional density.

According to the literature data, the adsorption of organic matter occurs on the partially filled $d$-orbital of ferrum by the reaction centres of molecules. It has been established that corrosion inhibitors usually promote the formation of a chelate on the metal surface, which include transfer of electrons from the organic compounds to the metal, forming a donor-acceptor bond during the chemical adsorption process.

According to Koopman's theorem [19], the frontier orbital energies $E_{\text {HOMO }}$ and $E_{L U M O}$ are related to the ionization potential, $I$, and the electron affinity, $A$, of iron and the inhibitor molecule by the following relations: $A=-E_{\text {LUMO }} ; I=-E_{\text {HOMO }}$.

In this adsorption, the metal acts as an electrophile while the inhibitor acts as a nucleophile. Considering the charge transfer characteristics of the adsorption, the wide use of quantum chemical calculations to study this process is justified. Calculated electron charges on the atoms of molecules were determined by their ability to chemical interaction, and by the wave function of the higher occupied molecular orbital, and the lower free molecular orbital, the most probable adsorption centers and the predictive adsorption capacity of the compounds were determined. In addition, it is known that the more negative charge on a heteroatom is the better the transfer of electrons from the donor occurs. Taking into account the characteristics of the transfer of charge of adsorption, the literature substantiates the widespread use of quantum-chemical calculations for the study of this process $[17,18]$.

Pearson and Parr have presented definitions using the finite differences method depending on electron affinity $(A)$ and ionization energy $(I)$ of any chemical species (atom, ion or molecule) for chemical hardness $(\eta)$, and chemical potential $(\chi)$. According to the theory of functional density, the absolute electronegativity $(\chi)$ and chemical potential $(\mu)$ are the main parameters that characterize the ability of molecules to chemically interact [20-23]. The chemical potential, electronegativity, chemical hardness of an electronic system is defined as:

$$
\begin{aligned}
\chi=-\mu & =\frac{1}{2}(I+A) \\
\eta & =\frac{1}{2}(I-A) .
\end{aligned}
$$

The global electrophilicity index $(\omega)$ was introduced by Parr et al. [24-25] and is given by:

$$
\omega=\frac{(I+A)^{2}}{8(I+A)}
$$

If the adsorption process is considered from the point of view of the acid-basic interaction, the important quantitative parameters characterizing this process are the degree of charge transfer $\Delta N$, i.e. the interaction strength of acid-acceptor molecules (iron surface) and the donor base (investigated substances of the vapor phase of the extract) and the magnitude of the energy change that accompanies the formation of the complex. The electron charge transfer, $\Delta N$, from base $B$ to acid $A$, and the associated energy change $\Delta E$ is given as:

$$
\begin{gathered}
\Delta N=\frac{\mu_{B}-\mu_{A}}{2\left(\eta_{A}+\eta_{B}\right)} \\
\Delta E=\frac{\left(\mu_{B}-\mu_{A}\right)^{2}}{2\left(\eta_{A}-\eta_{B}\right)}
\end{gathered}
$$

where $\chi=-\mu$ - electronegativity, $\mathrm{eV} ; \eta$ - chemical hardness, eV; $A$ - characteristics of the test substance molecule; $B$-characteristics of the elemental lattice of the iron surface.

The electronegativity of metal surface is replaced by the work function for $\mathrm{Fe}(110)$ surface, which is theoretically equal to $4.82 \mathrm{eV}$ and the hardness of metal is equal to $0 \mathrm{eV}$ for bulk metals [26].

Quantum chemical calculations have been performed by the HyperChem 7 [27] package. The geometry optimization was obtained by application of the restricted Hartree-Fock method (RHF) using MNDO approach with PM3 parameterization.

These parameters will provide insights into the mechanism of the interaction of the extract components with mild steel surface. 


\section{Results and Discussion}

\subsection{Inhibition of Mild Steel Vorrosion by the Film Formed from the Grape Pomace Extract}

Visual inspection was carried out following the criterion for the volatile corrosion inhibition test. Corrosion rate and inhibition effectiveness for the test samples are shown in Table 1.The analysis of the results of accelerated corrosion tests has shown that the volatile fractions of the extract protect steel from corrosion under the conditions of periodic moisture condensation. The corrosion rate and inhibition effectiveness for the extract film-forming specimens were $0.0186 \mathrm{~g} / \mathrm{m}^{2}$ and $90.05 \%$, respectively.

The influence of pre-treatment immersion time of steel in the volatile phase of the grape pomace extract on corrosion effect under the conditions of periodic moisture condensation was investigated. It should be noted that the corrosion rate decreases with the increase of film formation time. The inhibition efficiency (IE) increases in the range of $50.06-90.05 \%$. This shows that grape pomace extract can volatilize and adsorb on the carbon steel surface to protect the steel. It should be noted that the treatment of specimens in the vapor phase of individual 2-propanol does not improve the corrosion resistance of the metal. This allows us to recommend this extract for the corrosion protection of mild steel.

\subsection{Characterization of Grape Pomace Extract by GC-MS}

In the volatile fraction of the grape pomace extract 22 compounds were detected by the chromatography-andmass spectrometry method (Table 2). The important aldehydes, namely, hexanal $(9.1 \%)$, heptanal (8.7\%), 2-phenylacetaldehyde (6.5\%), butanal (4.8\%), nonanal ( $7.0 \%)$, and (2E)-3,7-dimethyl-2,6-octadien-1-ol (2.3\%) were found.
Other classes of compounds including terpenes, saturated and unsaturated fatty acids (34\%) represented by hexadecanoic acid (5.4\%), (9Z)-octadec-9-enoic acid (6.1\%), and (9Z,12Z)-9,12-octadecadienoic acid (4.2\%) were discovered. This result indicates that grape pomace extract contains aldehydes in their composition, which can act as corrosion inhibitors. For example, aldehydes and terpenes are the main compounds that provide protective effects of rapeseed cake extract as volatile corrosion inhibitor [13-15].

\subsection{Q uantum Chemical Study}

The inhibitor molecules structure of 2-propanol grape pomace extract (1-7) obtained after a geometric optimization procedure are presented in Fig. 1. The results of quantum-chemical calculations of the energy parameters of molecules are presented in Tables 3 and 4 . The HOMO energy $\left(E_{\text {НОМо }}\right)$ is often associated with the electron donating ability of the molecule, whereas the $E_{L U M O}$ indicates the ability of the molecule to accept electron. Therefore, high values of the $E_{\text {НОмо }}$ indicate an increased tendency of the inhibitor to donate electron to the vacant $d$-orbital of $\mathrm{Fe}$ in mild steel. Namely, the HOMO regions for the molecules are the sites at which electrophiles attack and represent the active centers with the utmost ability to interact with the metal surface atoms. The highest $E_{\text {Номо values are obtained for }}$ 2-phenylacetaldehyde, (2E)-3,7-dimethyl-2,6-octadien-1ol, and (9Z)-octadec-9-enoic acid. It is well known that the lower the $E_{L U M O}$ value, the greater the molecule ability to accept electrons from the metal $[17,18]$.

Our calculations have shown that investigated molecules have the lowest $E_{\text {LUMO }}$, so they have the greatest ability to interact with the metal surface. The ranking of the molecules according to their ability to accept electrons from mild steel is: 2-phenylacetaldehyde, (2E)-3,7-dimethyl-2,6-octadien-1-ol, butanal, nonanal, hexanal, (9Z)-octadec-9-enoic acid, and hexadecanoic acid.

Table 1

Calculated corrosion rates and inhibition efficiency obtained by weight loss method

\begin{tabular}{|c|c|c|}
\hline Time film-forming & Corrosion rates, $\mathrm{g} \mathrm{m}^{-2} \mathrm{~h}^{-1}$ & Inhibition efficiency IE, \% \\
\hline 12 & 0.0938 & 50.06 \\
\hline 24 & 0.0770 & 67.99 \\
\hline 30 & 0.0610 & 71.52 \\
\hline 35 & 0.0526 & 72.39 \\
\hline 40 & 0.0518 & 90.05 \\
\hline 48 & 0.0186 & 91.00 \\
\hline 72 & 0.0178 & - \\
\hline
\end{tabular}


The content of the main components the grape pomace extract

\begin{tabular}{|c|c|c|}
\hline Component & $\begin{array}{l}\text { Holding } \\
\text { time } t \text {, } \\
\text { min }\end{array}$ & $\begin{array}{c}\text { Weigh } \\
\text { t ratio, } \\
\%\end{array}$ \\
\hline Hexanal & 3.55 & 9.1 \\
\hline Heptanal & 3.75 & 8.7 \\
\hline 2-Phenylacetaldehyde & 3.87 & 6.5 \\
\hline Butanal (Butyraldehyde) & 4.13 & 4.8 \\
\hline Nonanal & 4.41 & 7.0 \\
\hline (2E)-3,7-Dimethyl-2,6-octadien-1-ol & 6.52 & 2.3 \\
\hline Propane-1,2,3-triol (Glycerol) & 6.60 & 0.9 \\
\hline 4-Hydroxy-3,5-dimethoxybenzaldehyde (Syringaldehyde) & 6.92 & 1.1 \\
\hline (2E)-3-Phenylprop-2-enal (Cinnamaldehyde) & 9.48 & 0.9 \\
\hline 4-Hydroxy-3-methoxybenzaldehyde (Vanillin) & 12.20 & 1.1 \\
\hline 2-methyl-2-propanyl 4-hydroxy-4-methyl-5-hexanoate & 13.57 & 4.8 \\
\hline Heptacosane & 17.31 & 3.2 \\
\hline (9Z,12Z)-9,12-Octadecadienoic acid (Linoleic acid) & 18.09 & 4.2 \\
\hline Hexadecanoic acid(Palmitic acid) & 18.24 & 5.4 \\
\hline (9Z)-Octadec-9-enoic acid (Oleic acid) & 19.62 & 6.1 \\
\hline $\begin{array}{l}\text { (1R,4E,9S)-4,11,11-Trimethyl-8-methylidenebicyclo[7.2.0]undec-4-ene } \\
\text { (Caryophyllene) }\end{array}$ & 21.01 & 1.7 \\
\hline (Naphthalene-1-yl) (1-pentyl-1H-indol-3-yl) methanone & 22.86 & 6.2 \\
\hline 2-(4-Methyl-1-cyclohex-3-enyl)propan-2-ol ( $\alpha$-Terpineol) & 23.94 & 9.5 \\
\hline 1-Methyl-4-(1-methylethylidene)cyclohexan-1-ol ( $\gamma$-Terpineol) & 24.01 & 4.2 \\
\hline $\begin{array}{l}\text { (1R,3aR,5aR,5bR,7aR,9S,11aR,11bR,13aR,13bR)-3a,5a,5b,8,8,11a-hexamethyl-1-prop-1-en-2-yl- } \\
1,2,3,4,5,6,7,7 \mathrm{a}, 9,10,11,11 \mathrm{~b}, 12,13,13 \mathrm{a}, 13 \mathrm{~b}-\text { hexadecahydrocyclopenta[a]chrysen-9-ol (Lupeol) }\end{array}$ & 24.52 & 9.5 \\
\hline Lup-20(29)-ene-3ß,28-diol (Betulin) & 27.41 & 3.8 \\
\hline
\end{tabular}

The separation energy is a parameter which determines the reactivity of a molecule towards a metallic surface and is a very important stability index. As $\Delta \varepsilon$ decreases, the reactivity of the molecule increases leading to increasing adsorption on the metal surface and hence high inhibition efficiency, since the energy to remove an electron from the last occupied molecular orbital will be low. The calculations from Table 4 show the following increasing reactivity abilities of the molecules towards steel: phenylacetaldehyde, 3,7-dimethylocta-2,6-dienal, (9Z)-octadec-9-enoic acid, butanal, nonanal, hexanal, and hexadecanoic acid. Consequently, the first substances of the specified series are likely to be more potent inhibitors.

Corrosion inhibition of mild steel by organic inhibitors (present in plant extracts) is a complex process and is mainly influenced by charge transfer. Electrophilicity, $\omega$, is an index which measures the propensity of chemical specie to accept electrons. Thus, a good nucleophile is characterized by low values of $\mu$ and $\omega$; whereas a good electrophile is characterized by high values of $\mu$ and $\omega$. It is clear from Table 4 that the molecules have low electrophilicity index values and are good nucleophiles.

The calculated amount of charge transfer, $\Delta N$, between the molecules and the mild steel Fe surface is given in Table 4. A positive value of $\Delta N$ indicates that the molecules act as an electron acceptor, while a negative value of $\Delta N$ indicates that the molecules act as electron donors. Thus, from Table 4 , all the molecules studied act as electron acceptors except $\Delta E$, which acts as electron donor. According to I. Lukovits [28], if $\Delta N<3.6$, the molecules can be assumed to possess charge transfer ability towards the metal surface. The molecules studied possess charge transfer abilities towards mild steel. The inhibition potential of 2-propanol grape pomace extract is attributed to the presence of aldehydes phenylacetaldehyde, 3,7-dimethylocta-2,6-dienal and (9Z)-octadec-9-enoic acid.

\subsection{Electrochemical Measurements}

The immersion time effect was investigated using potentiodynamic polarization. In analyzing the influence of VIC films on the rate of the partial electrode processes of anodic oxidation of steel and cathodic reduction of the molecular atmospheric oxygen in a $0.5 \mathrm{M} \mathrm{Na}_{2} \mathrm{SO}_{4}$ solution with and without protective films, it was discovered that, independently of the fact whether the VIC films are present or absent on the steel surface, the rate of the cathodic processes is much higher than the rate of anodic processes (Fig. 2). These dependences of the current density on the electrode potentials indicate the presence of fairly complicated multistage processes under the 
conditions of cathodic and anodic polarization of steel. Both the cathodic slopes and the anodic slopes do not change obviously, which indicates that the mechanism of the corrosion reaction does not change, and the corrosion reaction is inhibited by a simple adsorption mode. In other words, the inhibitor decreases the surface area for corrosion without affecting the mechanism of corrosion and only causes inactivation of a part of the metal surface.

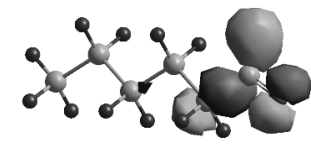

$E_{\text {Номо }}$

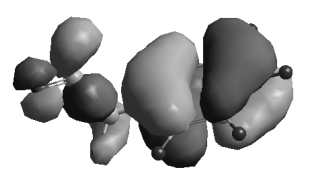

$E_{\text {Номо }}$

Hexanal

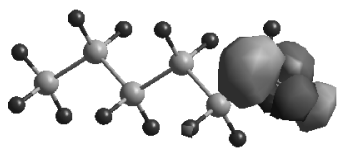

$E_{\text {LUMO }}$

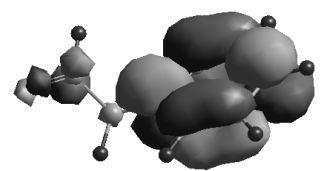

$E_{\text {LUMO }}$

2-Phenylacetaldehyde

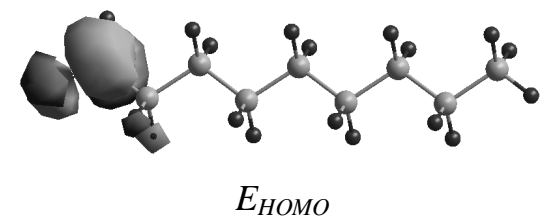

Nonanal

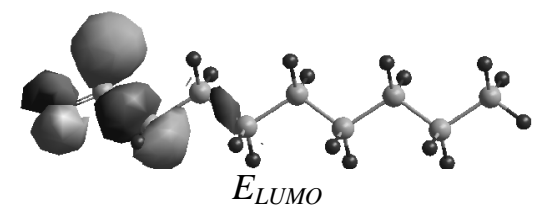

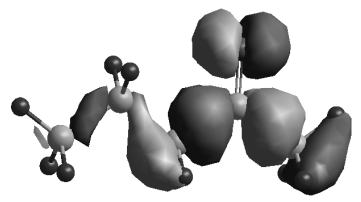

$E_{\text {Hомо }}$

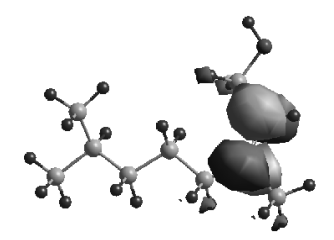

$E_{\text {Номо }}$

(2E)-3-Phenylprop-2-enal

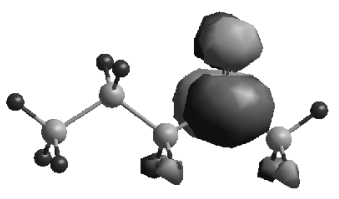

$E_{\text {LUMO }}$

Butanal

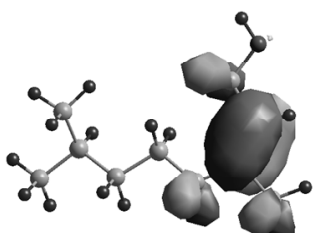

$E_{\text {LUMO }}$

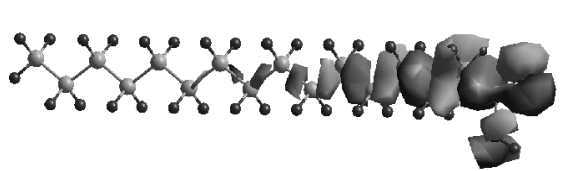

$E_{\text {Номо }}$

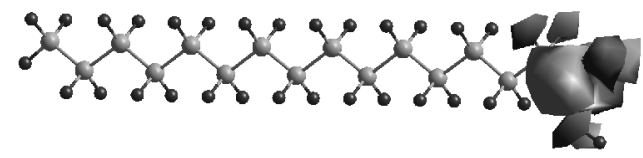

$E_{\text {LUMO }}$

Hexadecanoic acid

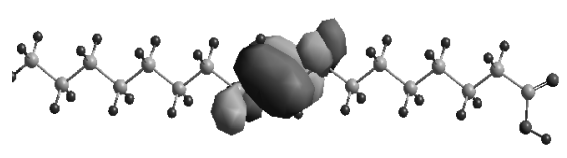

$E_{\text {НОмо }}$

(9Z)-Octadec-9-enoic acid

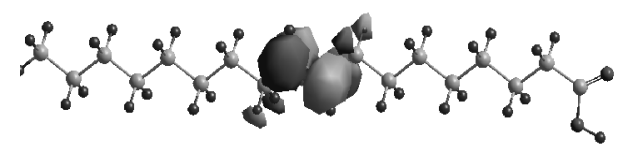

$E_{\text {LUMO }}$

Fig. 1. The frontier molecular orbital density distribution in the main components of grape pomace extract using quantum chemical calculations (orbital density value 0.005 ) 
Calculated quantum chemical properties for the most stable conformations of the major effective components of grape pomace extract

\begin{tabular}{|l|c|c|c|}
\hline \multicolumn{1}{|c|}{ Molecule } & $E_{H O M O}, \mathrm{eV}$ & $E_{L U M O}, \mathrm{eV}$ & $\Delta \varepsilon_{H-L}, \mathrm{eV}$ \\
\hline Hexanal & -10.771 & 0.864 & -11.63 \\
\hline 2-Phenylacetaldehyde & -9.908 & 0.125 & -10.03 \\
\hline Nonanal & -10.761 & 0.864 & -11.62 \\
\hline Butanal & -10.666 & 0.757 & -11.42 \\
\hline (2E)-3,7-Dimethyl-2,6-octadien-1-ol & -9.766 & 0.735 & -10.50 \\
\hline (9Z)-Octadec-9-enoic acid & -9.883 & 0.907 & -10.79 \\
\hline Hexadecanoic acid & -11.183 & 1.066 & -12.24 \\
\hline
\end{tabular}

Table 4

Calculated quantum chemical properties for the most stable conformations of the major effective components of grape pomace extract

\begin{tabular}{|l|c|c|c|c|c|}
\hline \multicolumn{1}{|c|}{ Molecule } & $\mu, \mathrm{eV}$ & $\eta, \mathrm{eV}$ & $\Delta N$ & $\omega$ & $\Delta E$ \\
\hline Hexanal & -4.95 & 5.81 & 0.175 & 1.238 & 0.00077 \\
\hline 2-Phenylacetaldehyde & -4.89 & 5.01 & 0.210 & 1.222 & 0.00025 \\
\hline Nonanal & -4.94 & 5.81 & 0.176 & 1.237 & 0.00071 \\
\hline Butanal & -4.94 & 5.72 & 0.179 & 1.236 & 0.00068 \\
\hline (2E)-3,7-Dimethyl-2,6-octadien-1-ol & -4.51 & 5.25 & 0.236 & 1.128 & 0.00440 \\
\hline (9Z)-Octadec-9-enoic acid & -4.48 & 5.39 & 0.232 & 1.220 & 0.00510 \\
\hline Hexadecanoic acid & -5.05 & 6.12 & 0.158 & 1.264 & 0.00232 \\
\hline
\end{tabular}

As the time of treatment of the metal by the volatile compounds of extract is increased to $48 \mathrm{~h}$, the increase in the inhibiting efficiency becomes especially visible. It is also seen that all these samples change the corrosion potential significantly to positive direction, and, therefore, they are predominantly anodic-cathodic inhibitors.

The inhibition efficiency increases as the pretreatment immersion time is increased. Both anodic and cathodic reactions are drastically inhibited after $72 \mathrm{~h}$ of exposure to the film-forming. In the presence of volatile compounds extract, the slight change of both $b_{c}$ and $b_{a}$ indicates that the corrosion mechanism of steel does not change. These results infer that the inhibitor acts by simple blocking of the available surface area. These components can be classified as mixed-type inhibitors.

Fig. 3 represent the Nyquist diagrams for steel in $1 \mathrm{~N} \mathrm{Na}_{2} \mathrm{SO}_{4}$ without protective film (curve 1) and with a film formed after holding for $48 \mathrm{~h}$ in the vapor phase of grape pomace extracts (curve 2). The most common equivalent circuit used to model corrosion of the metal in aqueous electrolyte is the Randles circuit (Fig. 4, Table 5).

The Nyquist diagram of steel in the absence of protective film describes a capacitive arc with high frequency values, which is followed by a straight line at lower frequency values. In the presence of protective film, the impedance spectrum switches to double-capacitive semicircles. The disappearance of the diffusion features in the presence of protective film indicates that the corrosion reaction is inhibited by protective film, which makes the diffusion process to be non-controlled one. Furthermore, the inhibition efficiencies obtained from weight loss and polarization curves are in reasonably good correlation.

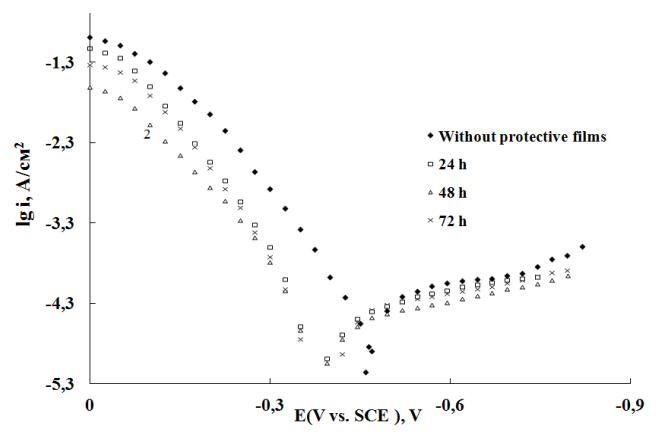

Fig. 2. Polarization curves for steel in $0.5 \mathrm{M} \mathrm{Na}_{2} \mathrm{SO}_{4}$ at different time of film formed in vapour phase of grape pomace extract

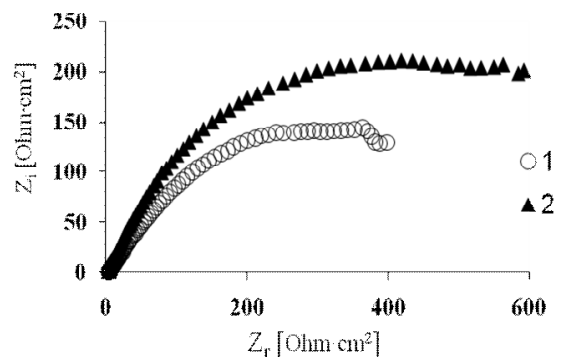

Fig. 3. Nyquist plots measured at $E_{\text {corr }}$ of steel in $1 \mathrm{~N} \mathrm{Na}_{2} \mathrm{SO}_{4}$ without protective film (1) and with a film formed after holding for $48 \mathrm{~h}$ (2) in the vapor phase of the volatile compounds of grape pomace extract 
The results obtained from weight loss and potentiodynamic polarization are in good agreement, and the compounds inhibition action could also be evidenced by surface SEM images.

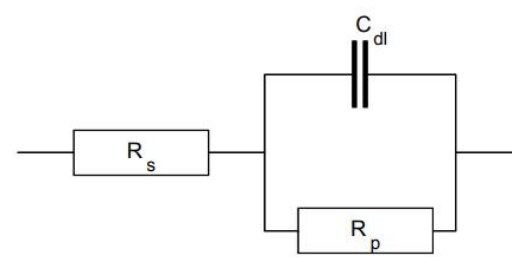

Fig. 4. Equivalent circuits for test steel

\subsection{SEM Surface Examination}

To establish whether corrosion inhibition is due to formation of green inhibitor protective film on the metal surface, SEM images were taken. The surface morphology of the sample before exposure to volatiles of extract indicates that there were a few scratches from the mechanical polishing treatment. This image displays a freshly polished steel surface. The following images (Figs. $5 \mathrm{~b}, \mathrm{c})$ are showing the steel surface after $48 \mathrm{~h}$ of exposure in vapor phase of grape pomace extract for the filmforming. A thin film covering surface can be seen.

FT-IR analysis of the carbon steel specimens in the absence and after the film formation for $72 \mathrm{~h}$ in the gasvapor atmosphere in the presence of extract was carried out between 500 and $4000 \mathrm{~cm}^{-1}$.
The IR-spectrum of the extract are characterized by the presence of an intense absorption band of $\mathrm{C}=\mathrm{O}$ groups at a wavelength of $1400 \mathrm{~cm}^{-1}$ in the carbonic groups of fatty acids, which confirms the presence of significant amounts of saturated and unsaturated fatty acids in the extract. Absorption bands in the interval of $900-690 \mathrm{~cm}^{-1}$ are referred to the vibrations of aromatic substitutes (deformation vibrations of the $\mathrm{C}-\mathrm{H}$ bond) and the deformation vibrations within the range of $1300-1200 \mathrm{~cm}^{-1}$ corresponding to the alcohol groups. The strong band at $\sim 3440 \mathrm{~cm}^{-1}$ can be associated with $\mathrm{O}-\mathrm{H}$ stretching of the phenolic group. The band at $2981 \mathrm{~cm}^{-1}$ is related to $\mathrm{C}-\mathrm{H}$ stretching vibration. The strong band at $1640 \mathrm{~cm}^{-1}$ is assigned to conjugated $\mathrm{C}=\mathrm{O}$ stretching vibration. The band at $1452 \mathrm{~cm}^{-1}$ can be attributed to $\mathrm{C}=\mathrm{C}-\mathrm{C}$ aromatic ring stretching. The absorption bands within the interval of $1750-1600 \mathrm{~cm}^{-1}$ are related to the stretching vibrations of carbonyl groups of aldehydes and the vibrations of aromatic rings. The bands at 1045 and $1087 \mathrm{~cm}^{-1}$ can be assigned to $\mathrm{C}-\mathrm{H}$ deformations of the aromatic ring.

So, after $48 \mathrm{~h}$ (Fig. 6, curve 2) of film formation one can observe the decrease in the oscillation intensity in the region of $1800-1580 \mathrm{~cm}^{-1}$, which is more characteristic of aldehydes, and the appearance of intense absorption bands in the region of $1680-1640 \mathrm{~cm}^{-1}$, which is inherent in $v(\mathrm{C}=\mathrm{C})$ groups, as well as the emergence of intensive absorption bands of valence bonds in the region of $2800-2500 \mathrm{~cm}^{-1}$, corresponding to two groups of compounds - dimeric and trimeric polymer adducts.

Table 5

Typical parameters obtained from EIS fitting results of $\mathrm{St} 3$ steel in $1 \mathrm{~N} \mathrm{Na}_{2} \mathrm{SO}_{4}$ without protective film and with a film formed after holding for $48 \mathrm{~h}$ in the vapor phase of grape pomace extract

\begin{tabular}{|l|c|c|c|c|}
\hline \multirow{2}{*}{\multicolumn{1}{|c|}{ Sample }} & \multicolumn{3}{|c|}{ Parameters obtained from EIS fitting results } \\
\cline { 2 - 5 } & $R_{1}, \mathrm{Ohm} \cdot \mathrm{cm}^{2}$ & $R_{2}, \mathrm{Ohm} \cdot \mathrm{cm}^{2}$ & $C P E_{1}, \mu \mathrm{F} / \mathrm{cm}^{2}$ & $W^{*}, \mathrm{Ohm} \cdot \mathrm{cm}^{2}$ \\
\hline Without protective films & 3.76 & 586 & 26 & - \\
\hline With protective films & 3.97 & 812 & 20 & - \\
\hline
\end{tabular}

Note: $W$ - resistance of Warburg, which is connected with diffusion limitation (resistance of electrolyte in pores)

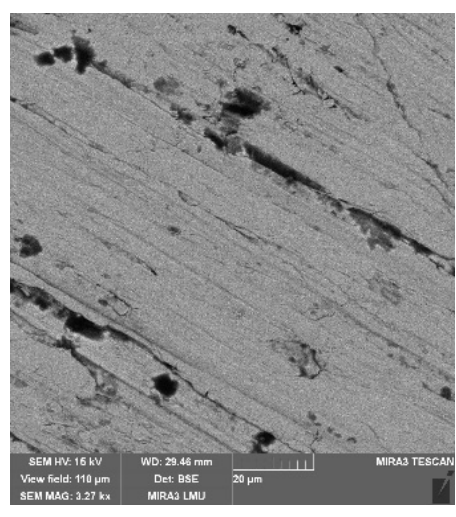

a)

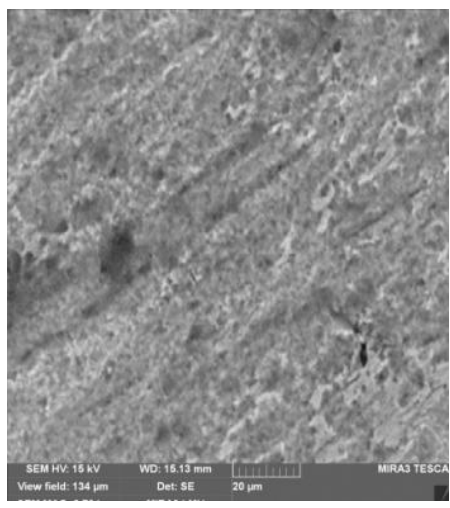

b)

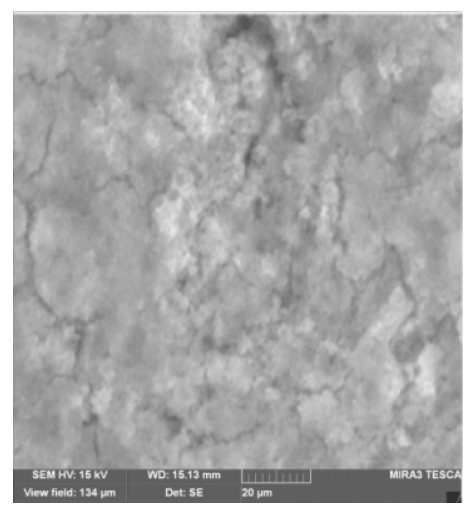

c)

Fig. 5. SEM images of the carbon steel surface: initial surface (a); after 24 (b) and 48 (c) h in vapor phase of extract 


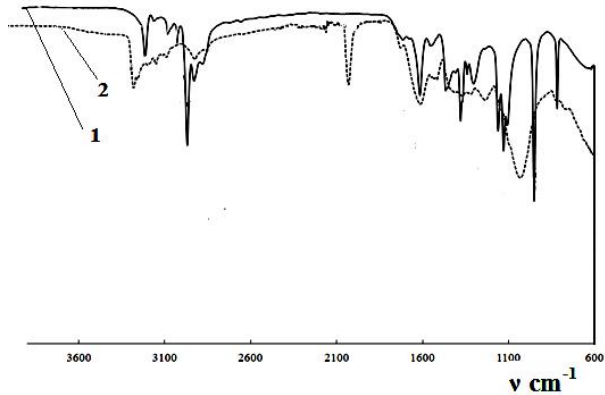

Fig. 6. FT-IR spectrum of grape pomace extract (1) and IR spectrum of St3 surface treated by volatile compounds of grape pomace extract (2) for $48 \mathrm{~h}$

The shifts oscillations in the region of 1800$1580 \mathrm{~cm}^{-1}$, with respect to the individual compounds, indicate that there is interaction between $\mathrm{Fe}$ in the mild steel and some molecules of the inhibitor. It is also evident from the analyzed FT-IR spectrum that after the initial mechanism of physical adsorption, chemical adsorption of the inhibitor molecules on Fe (in mild steel) also occurred.

The inhibition efficiency of 2-propanol grape pomace extract is attributed to joint adsorption of some phytochemical constituents. Therefore, it is recommended to use the grape pomace extract as a corrosion inhibitor of mild steel under the conditions of periodic moisture condensation.

\section{Conclusions}

In this study it was shown that the grape pomace extract is an effective corrosion inhibitor applied for the temporary protection of mild steel. The results evidenced that green inhibitor showed excellent performance (more than $90 \%$ ) as the corrosion inhibitor. Under conditions of modeling the atmospheric corrosion of mild steel, the VIC films from the developed components decrease the rate of cathodic and anodic process. In this case, the rate of corrosion is controlled by the cathodic process of molecular oxygen reduction from air. Presumably, the inhibitory effect was performed via the adsorption of compounds present in the grape pomace extract onto the steel surface. The quantum-chemical calculations were carried out to predict the adsorption activity of the main components of grape pomace extract. It is shown that the inhibition of steel atmospheric corrosion after treatment in the vapor of volatile compounds of the 2-propanol grape pomace extract occurs due to the blocking of the metal surface by chemically adsorbed molecules. The anticorrosion efficiency of the extract is ensured by 2-phenylacetaldehyde, 3,7-dimethylocta-2,6-dienal and (9Z)-octadec-9-enoic acid.

\section{References}

[1] Zhang D.-Q., Gao L.-X., Zhou G.-D.: Surf. Coat. Technol., 2010, 204, 1646. https://doi.org/10.1016/j.surfcoat.2009.10.054 [2] Zhang D.-Q, An Z.-H., Pan Q.-Y. et al.: Corros. Sci., 2006, 48, 1437. https://doi.org/10.1016/j.corsci.2005.06.007

[3] Quraishi M., Jamal D.: Corrosion, 2002, 58, 5, 387.

https://doi.org/10.5006/1.3277627
[4] Bastidas D., Cano E., Mora E.: Anti-Corrosion Methods and Materials, 2005, 52, 71. https://doi.org/10.1108/00035590510584771 [5] Andreatta F. Fedrizzi L.: Active Protectiv Coatings, 2016, 233, 59. https://doi.org/10.1007/978-94-017-7540-3_4

[6] Taleb H. Ibrahim, Elron E. Gomes, Ime B. Obot et al.: J. Adhes. Sci. Technol., 2017, 31, 2697. https://doi.org/10.1080/01694243.2017.1317458

[7] Raja P., Sethuraman M.: Mat. Lett., 2008, 62, 113.

https://doi.org/10.1016/j.matlet.2007.04.079

[8] Abd-El-Nabey B., Abdel-Gaber A., Said Ali M. et al.: Int. J. Electrochem. Sci., 2013, 8, 7124.

[9] Radojc`ic' I., Berkovic' K., Kovac`S., et al.: Corros. Sci., 2008, 50, 5 1498. https://doi.org/10.1016/j.corsci.2008.01.013

[10] Poongothai N., Rajendran P., Natesan M. et al.: Indian J. Chem. Technol., 2005, 12, 641.

[11] Premkumar P., Kannan K., Natesan M.: Asian J. Chem., 2008, 20, 445 [12] Premkumar P., Kannan K., Natesan M.: J. Metall. Mat. Sci., 2008, 50, 227.

[13] Vorob'iova V., Chyhyrynets' O., Vasyl'kevych O.: Mater. Sci., 2015, 50, 726. https://doi.org/10.1007/s11003-015-9778-z

[14] Chygyrynets' E., Vorobyova V.: Chem. Chem. Technol., 2014, $8,235$.

[15] Chyhyrynets O., Vorob'iova V.: Mater. Sci., 2013, 49, 318. https://doi.org/10.1007/s11003-013-9617-z

[16] Leygraf C., Wallinder I., Tidblad J., Graedel T.: Atmospheric Corrosion, John Wiley \& Sons, Inc., Hoboken 2016.

[17] Kaya S., Tüzün B., Kaya C., Obot I.: J. Taiwan Inst. Chem. Eng., 2016, 58, 528. https://doi.org/10.1016/j.jtice.2015.06.009

[18] Gece G.: Corros. Science, 2008, 50, 2981.

https://doi.org/10.1016/j.corsci.2008.08.043

[19] Koopmans T.: Physica, 1934, 1, 104. https://doi.org/10.1016/S0031-8914(34)90011-2

[20] Kovacevic N., Kokalj A.: Corrosion Science 2011, 53, 909. https://doi.org/10.1016/j.corsci.2010.11.016

[21] Parr R., Pearson R.: J. Am. Chem. Soc., 1983, 105, 7512. https://doi.org/10.1021/ja00364a005

[22] Parr R., Donnelly R., Lewy M., Palke W.: J. Chem. Phys., 1978, 68, 3801. https://doi.org/10.1063/1.436185

[23] Pearson R.: Proc. Natl. Acad. Sci. USA, 1986, 83, 8440. https://doi.org/10.1073/pnas.83.22.8440

[24] Chattaraj P., Sarkar R., Roy D.: Chem. Rev., 2006, 106, 2065. https://doi.org/10.1021/cr040109f

[25] Parr R., von Szentpaly L., Liu S.: J. Am. Chem. Soc., 1999, 121, 1922. https://doi.org/10.1021/ja983494x

[26] Kaya S., Kaya C.: Comput. Theor. Chem., 2015, 1052, 42. https://doi.org/10.1016/j.comptc.2014.11.017

[27] HyperChem ${ }^{\mathrm{TM}}$, Hypercube, Inc., Ontario, Canada 1994.

「281 Lukovits I., Kálmán E., Zucchi F.: Corrosion. 2001, 57, 3. https://doi.org/10.5006/1.3290328

Received: August 01, 2017 /Revised: September 19, 2017 / Accepted: January 04, 2018

\section{ДОСЛЬЖЕННЯ ЕКСТРАКТУ ЖМИХУ ВИНОГРАДУ ЯК ЕКОЛОГІЧНО БЕЗПЕЧНОГО ЛЕТКОГО ІНГІБІТОРУ КОРОЗІЇ СТАЛІ}

Анотація. Екстракт жмиху винограду досліджено як новий екологічно безпечний леткий інгібітор атмосферної корозії сталі. Протикорозійні властивості очінено масометричним та електрохімічними методами. Методом ІЧ-спектроскопї та газової хромато-мас-спектрометрії досліджено компонентний складу ізопропанольного екстракту жмиху винограду. Досліджено морфологію захисної плівки. Для оцінки адсорбиійної здатності головних компонентів рослинного екстракту проведені квантово-хімічні розрахунки енергетичних параметрів молекул.

Ключові слова: екстракт жмиху винограду, леткий інгібітор корозї сталі, альдегіди, квантово-хімічні розрахунки. 